\title{
Improvement of inventory control and cost efficiency Warteg ABC
}

\author{
Fariz Qasmal Maulana ${ }^{1 *}$, Anton Wachidin Widjaja ${ }^{2}$ \\ ${ }^{1}$ Magister Management Faculty of Economic and Business, Indonesia University \\ ${ }^{2}$ Faculty of Economic and Business, Indonesia University
}

\begin{abstract}
This thesis discusses about case study Micro, Small, and Medium Enterprise (MSME) inventory control which is engaged in food and beverages industry, students of the Faculty of Economics and Business of UI, of 2020. The increasing number of MSMEs which is engaged in food and beverages industry has positive impact to the economy of Indonesia, but also leads to the increases of competitiveness among MSMEs. To compete with others in the food and beverages industry which is always growing year by year, MSMEs should be able to manage the inventory professionally. Warteg $\mathrm{ABC}$ is a MSME, engaged in the food and beverages industry, which is sell Indonesian cuisine. Warteg $\mathrm{ABC}$ was already operated for more or less 4 years in South Jakarta. Data is obtained using business coaching method, a qualitative research from the interview with the owner and observation, to mapping the MSME's conditions and problems, continued with the corrective action to implement solution. The result shows that Warteg $\mathrm{ABC}$ did not have proper record for the inventory purchase decision, the amount of inventory and the calculation of inventory cost in managing their business on the daily activities. Thus, the solution that given is to improve the inventory control and cost efficiency. Implementation assessment can't be carried out to support the results of the improvements because of the Covid-19 Pandemic that makes the MSME decided to close temporarily. This research is aimed to help Warteg $\mathrm{ABC}$ to improve the inventory control and cost efficiency.
\end{abstract}

\section{Introduction}

In recent times, there are significant increase in the number of MSMEs in Indonesia. In 2010, the total number of MSMEs in Indonesia were 52.76 million and in 2018, the total number of MSMEs in Indonesia were becoming 64.2 million. In average, the total number of MSMEs in Indonesia increases $1.43 \%$ every year from 2010 to 2018 . The increase of total number of MSMEs in Indonesia is the cumulative from many types of industry, and one of them is the food and beverages industry. In 2017 and 2018, the food and beverages industry in Indonesia is increasing $9.23 \%$ and $7.91 \%$, respectively. (Ministry of Cooperatives and SMEs of Republic of Indonesia, 2018)

* Corresponding author: fariz.qasmal@,gmail.com 
The increasing number of total MSMEs in food and beverages industry in Indonesia year by year means that the competition to seize the market will be tighter. With this condition, every entrepreneur should be able to develop competitive advantage to maintain the customer and market well and develop their business to gain more profit. One of the ways to do this is that entrepreneur must be able to manage his business professionally with good inventory control to reduce fraud risk and have better inventory cost efficiency to lower the price and have better competitive advantage compare to the competitors.

In the business, supply chain of a firm often manages 60 to 70 percent of the cost, controls $100 \%$ of the inventory, and provides the foundation for all of the revenue generation [1]. This means that a MSME could have competition value if they have better inventory control for the purchasing and selling of the inventory that will lead to lower fraud risk, reduce inventory spoilage, inventory dead stock and result with better inventory cost efficiency. Also, if the purchasing activities are properly recorded and MSME could manage their supplier well, MSME can have better information related to the price of the ingredients that the suppliers offer and could choose the best supplier that provide the lowest ingredient cost. The capability of MSME to lowering cost of inventory than the competitor will be impact to the lower Cost of Goods Sold (COGS) calculation, which could result with lower price as the competitive advantages, generate more sales, and increase in the profit margin.

Warteg ABC is a MSME that owned by seven people and engaged in the field of food and beverages, which specialized in providing good qualities of Indonesian food with reasonable prices. Warteg $\mathrm{ABC}$ is providing kind of food and beverages such as rice, noodle, chicken, egg, squid, spinach, vegetables, ice tea, coffee, etc. The customers that Warteg ABC targeting are for the people who work and live near the store and deliver the foods to their house or office which are ordered by using their online mobile apps. Nowadays, Warteg ABC is facing tight competition in Jakarta. There are many brands in this industry which has faster growth in Jakarta, such as Warteg Kharisma Bahari which offers franchise and also Warteg Bahagia which already have some branches in Jakarta. To compete against these competitors, there are only two key success factors for the business to be success, innovation or cost leadership to have better competitive advantage compare to the competitor and have better market share which will result with gain more profit.

This paper aims to offer a new perspective on how MSMEs in the food and beverages industry can have better competitive advantage with the appliance of good inventory control, in order to lower the fraud risk and inventory cost to lower price and gain more profit. The paper is structured as follows. The next section outlines the theoretical background and the research questions, in order to have better understanding about the influence of inventory control supported by technologies in term of MSMEs competitiveness in food and beverages industry. The research methodology is described in Section 3, while the case study has been analyzed in the Section 4. The insight in terms of inventory control and technologies influenced to the MSME competitiveness resulting from the case study analysis are discussed in Section 5, which also provide some key challenges and suggestions for further research literature review. 


\section{Literature Review}

\subsection{Business Canvas Model}

Table 1. Business Canvas Model.

\begin{tabular}{|c|c|c|c|c|c|}
\hline \multirow[t]{2}{*}{$\begin{array}{l}\text { Key Partner } \\
-\quad \text { Supplier }\end{array}$} & 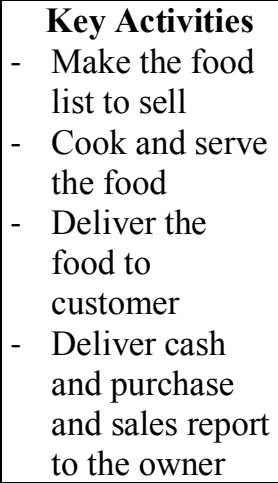 & \multirow{2}{*}{\multicolumn{2}{|c|}{$\begin{array}{l}\quad \text { Value } \\
\text { Proposition } \\
\text { Good } \\
\text { cleanliness } \\
\text { quality and } \\
\text { reasonable } \\
\text { price of } \\
\text { Indonesian } \\
\text { food }\end{array}$}} & $\begin{array}{l}\text { Customer } \\
\text { Relationship } \\
\text { - } \text { Social } \\
\text { network } \\
\text { (Instagram, } \\
\text { Facebook, } \\
\text { website) }\end{array}$ & \multirow{2}{*}{$\begin{array}{l}\text { Customer } \\
\text { Segment } \\
\text { - Behavioral: } \\
\text { Costumer that } \\
\text { needs to have } \\
\text { lunch or } \\
\text { dinner with } \\
\text { good } \\
\text { cleanliness } \\
\text { quality and } \\
\text { reasonable } \\
\text { price of } \\
\text { Indonesian } \\
\text { food } \\
\text { Geographic: } \\
\text { Offices and } \\
\text { houses in } \\
\text { South Jakarta } \\
\text { Demographic: } \\
\text { Customer } \\
\text { aged 22-60 } \\
\text { years old who } \\
\text { works in } \\
\text { Jakarta } \\
\text { Psychographic } \\
\text { : People who } \\
\text { live with low } \\
\text { to medium } \\
\text { social class }\end{array}$} \\
\hline & 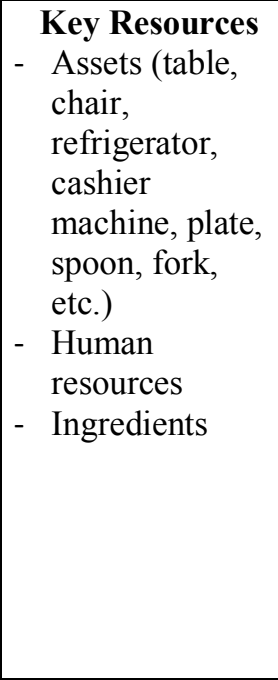 & & & $\begin{array}{ll} & \text { Channels } \\
- & \text { Store } \\
- & \text { Intermediary } \\
\text { enterprises }\end{array}$ & \\
\hline \multicolumn{3}{|c|}{\begin{tabular}{l}
\multicolumn{1}{c}{ Cost Structures } \\
Fixed cost: rent expense, employee's \\
salary, asset equipment \\
Variable cost: ingredients, gas, \\
electricity, water
\end{tabular}} & \multicolumn{3}{|c|}{$\begin{array}{c}\text { Revenue Streams } \\
\text { Receive order of the food or beverages }\end{array}$} \\
\hline
\end{tabular}




\subsection{SWOT Analysis}

Table 2. SWOT Analysis

\begin{tabular}{|ll|ll|}
\hline \multicolumn{1}{|c|}{ Strengths } & \multicolumn{1}{|c|}{ Weaknesses } \\
\hline$-\begin{array}{l}\text { Good cleanliness food with } \\
\text { competitive price } \\
\text { Strategic location }\end{array}$ & $-\begin{array}{l}\text { High potential fraud risk because } \\
\text { of lack inventory control } \\
\text { Marketing activities are not } \\
\text { managed well }\end{array}$ \\
\hline \multicolumn{1}{|c|}{ Opportunities } & \multicolumn{1}{|c|}{ Threats } \\
\hline$-\quad \begin{array}{l}\text { Big potential customer market in } \\
\text { Jakarta } \\
\text { Many potential suppliers in the } \\
\text { market } \\
\text { Potential digital marketing access }\end{array}$ & $-\begin{array}{l}\text { Competitive market } \\
\text { Potential new entrants } \\
\text { Imitable products } \\
\text { Substitute products } \\
\text { Bargaining power of buyers }\end{array}$ \\
\hline
\end{tabular}

Based on the SWOT analysis, TOWS matrix is made for the strategy improvement by examining relationship between strengths, weaknesses, opportunities, and threats. TOWS matrix will define the correlation between four factors systematically and establish the strategy based on the relationship.

Table 3. TOWS Matrix.

\begin{tabular}{|c|c|c|}
\hline & Strengths & Weaknesses \\
\hline & $\begin{array}{ll}- & \text { Good cleanliness food } \\
\text { - } & \text { with competitive price } \\
\text { - } & \text { Fancy food packaging }\end{array}$ & 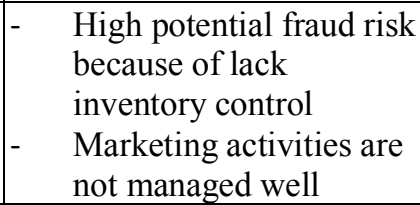 \\
\hline Opportunities & SO Strategy & WO Strategy \\
\hline $\begin{array}{ll}\text { - } & \text { Big potential customer } \\
\text { market in Jakarta } \\
\text { - } & \text { Many potential } \\
\text { suppliers in the market } \\
\text { - } \\
\text { Potential digital } \\
\text { marketing access }\end{array}$ & 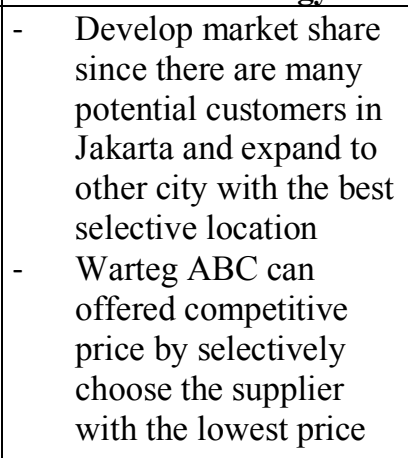 & $\begin{array}{l}\text { Operate inventory } \\
\text { control for the enterprise } \\
\text { to mitigate the fraud risk } \\
\text { with properly record } \\
\text { inventory transactions so } \\
\text { the enterprise can } \\
\text { operate effectively and } \\
\text { efficiently } \\
\text { Optimization of digital } \\
\text { marketing. }\end{array}$ \\
\hline Threats & ST Strategy & WT Strategy \\
\hline $\begin{array}{ll}- & \text { Competitive market } \\
- & \text { Potential new entrants } \\
- & \text { Imitable products } \\
- & \text { Substitute products } \\
- & \text { Bargaining power of } \\
& \text { buyers }\end{array}$ & $\begin{array}{ll}- & \text { Product innovation } \\
\text { - } & \text { Give more competitive } \\
\text { price and products to } \\
\text { the customers with } \\
\text { good analysis financial } \\
\text { plan }\end{array}$ & $\begin{array}{l}\text { Build a well-organized } \\
\text { enterprise to push the } \\
\text { fraud risk and cost, to } \\
\text { compete with other store } \\
\text { in the same industry }\end{array}$ \\
\hline
\end{tabular}

From the matrix above, WO strategy is chosen because it fits Warteg ABC problem. Inventory control is needed to lower fraud risk and reduce inventory cost to operate more efficiently and effectively, and result with lower price, sales increase, and gain more profit. 


\subsection{Weighted Pareto Gap}

Table 4. Weighted Pareto Gap

\begin{tabular}{|l|l|r|r|r|r|r|}
\hline No. & GAP & Score & Quality & Contribution & Distribution & Accumulation \\
\hline 1 & $\begin{array}{l}\text { Inventory } \\
\text { Control and } \\
\text { Cost } \\
\text { Efficiency }\end{array}$ & 10 & 9 & 90 & $51.72 \%$ & $51.72 \%$ \\
\hline 2 & $\begin{array}{l}\text { Marketing } \\
\text { Strategy }\end{array}$ & 7 & 7 & 49 & $28.16 \%$ & $79.89 \%$ \\
\hline 3 & Innovation & 5 & 7 & 35 & $20.11 \%$ & $100.00 \%$ \\
\hline & & & Total & 174 & $100.00 \%$ & \\
\hline
\end{tabular}

Based on Pareto gap analysis, discussion with the owner, and direct observation, the focus in this business coaching research is to do the improvement of inventory control and cost efficiency since this action will give highest impact amounted $51.72 \%$ as in Table 1 .

\subsection{How to Control Inventory}

According to Schwarz (2020), taking stock is just the process of determining what you have and where you store it so that you can evaluate it [2]. Not all inventory control procedures are ideal for every business or for the varying stages of an organization's growth and development. Some methods are too complicated, especially for smaller companies. MSMEs should be able to use system to track inventory levels, create orders and send out stock. Some basic systems for tracking inventory include:

- Simple Spreadsheets

Many companies, especially small businesses, use spreadsheets to track inventory. Whether they use Microsoft Excel or something similar, spreadsheets are a way to start automating and electronically capturing product data. With consistent updating and basic coding, it can ensure to have available current inventory levels and statistics. Businesses quickly customize these systems to meet their needs. Since everyone who builds a spreadsheet does so slightly differently, users will need intimate knowledge of how the sheet works. This method is also thought of as manual because the only way to automatically update the spreadsheet system is by adding high-level macros or coding that connects them with other systems.

- Basic Inventory Software

Simple inventory software is usually low cost and targeted to small and medium-sized businesses. This simple automation is often cloud-based and ties into point of sale software, so it can generate real-time, automatic stock updates. It can also incorporate analytics and reporting and run cost comparisons, create reorders, identify best and worst-selling products and drill down to order details or customer patterns. Some simple inventory management software systems can scale to more complex functionality as business grows.

Some businesses prefer to stick to the simple systems of keeping track of inventory. Other companies plan for growth and scaling. MSMEs could also track inventory with Advanced Software, designed for tracking inventory, most of these targeted software solutions can integrate with existing software, are scalable and provide analytics and templates. Advanced software is now in reach for many small and midsize businesses because it is no longer cost prohibitive. 
According to Campbell (2018), it's important to factor inventory into your cash flow management [3]. Inventory directly affects sales (by dictating how much you can sell) and expenses (by dictating what you have to buy), and both of these elements factor heavily into how much cash you have on hand. In short, better inventory management leads to better cash flow management. The following analysis techniques will help to improve inventory management and cash flow.

- Accurate Forecasting

A huge part of good inventory management comes down to accurately predicting demand. There are countless variables that will be involved.

- $\quad$ First-In First-Out

"First-in, first-out" is an important principle of inventory management. It means your oldest stock (first-in) gets sold first (first-out), not your newest stock. This analysis is important to reduce spoilage inventory and dead stock inventory.

- Manage relationships

Whether the business need to return a slow selling item to make room for a new product, restock a fast seller very quickly, troubleshoot manufacturing issues, or temporarily expand storage space, it's important to have a strong relationship with suppliers to solve problems together.

- Physical inventory

A physical inventory is the practice in counting all inventory at once. Many businesses do this at their year-end because it ties in with accounting and filing income tax. Although physical inventories are typically only done once a year, it can be incredibly disruptive to the business. If business find a discrepancy, it can be difficult to pinpoint the issue when you're looking back at an entire year.

According to Biswas et al. (2017), there are some additional different control techniques that can be used for inventory management: [4]

- Always Better Control (ABC) Analysis

$\mathrm{ABC}$ analysis (alternatively termed as "Selective Inventory Control") is widely used inventory categorization technique for managing stocked material that should be managed differently. This technique is based on Pareto principle and works in dividing items into three categories A, B and C in order of their level of significance. " $A$ " denotes items that are very expensive $\&$ require tight control, " $B$ " items are important $\&$ require moderate control, " $C$ " items are least important.

- Safety Stock

Safety stock is the stock held by a company in excess of its requirement for the lead time. Companies hold safety stock to guard against stock-out. As demand is uncertain, safety stock plays a vital role to satisfy demand if it exceeds the anticipated demand. Too much safety stock carried increases the holding cost of a supply chain. So, the key to the success of any supply chain is to make a balance between safety stock and level of customer satisfaction.

The application of simple spreadsheets, basic inventory software, and some analysis tools above will result in a significant reduction of cost. The successful implementation of above control and analysis will lower fraud risk, avoid spoilage stock better, avoid dead stock inventory, and choose the supplier that provides lowest cost with the same quality products. Lower cost will lead to lower price that will attend as the competitive advantages for MSMEs to compete with the other competitor in the industry, have more sales, and gain more profits. 


\section{Research Methodology}

In conducting this business coaching research methodology, a framework is needed as guide in doing this research study. The framework starts from data collection for the final activity in the business coaching. The aim of this study is in an action plan that form results. The first process of business coaching research study is start from interview with the owner. The second process is to do the direct observation to the Warteg ABC store. And the last process is about the discussion with the owner about the problem that occurs in Warteg $\mathrm{ABC}$ and how to solve them.

Based on the analysis from the previous section, this research will focus on the improvement of inventory control whether it is offline or online implementation and also the usage of some analysis that will help for the purchasing inventory decision.

\section{Results}

The implementation of the improvement of inventory in Warteg $\mathrm{ABC}$ was conducted in the purchasing and selling activities area. To improve the inventory control of Warteg ABC, the purchasing and selling activities should be properly recorded to mitigate the risk such as fraud risk, spoilage inventory, and dead stock inventory which will lead to the better inventory cost efficiency. The final result of this business coaching case study research is recorded information system in the Microsoft Excel form that will integrate the purchasing and selling activities of the inventory, so it will provide historical and actual data related to the balance of the inventory on the daily basis and also to have better information related to operation cost about how much the Cost of Goods Sold (COGS) for the inventory sold to the customers. Later, this information system can be automated by using POS software application, which will be integrated the inventory sold with the inventory balance. To strengthen the inventory control, the coach also gave some analysis tools that will help to improve inventory management and better cash flow, such as demand forecasting, ABC Analysis, set safety stock, FIFO inventory management, manage relationships with supplier and do physical inventory.

\section{Discussion}

\subsection{Implementation of Offline Improvement}

In the process of purchasing inventory, there are several analysis table that can be used to manage the inventory, such as demand forecasting that help the management decide how many inventory item that should be purchased, $\mathrm{ABC}$ analysis that help the management more focus on the critical inventory, and safety stock analysis that help management to make sure that there will never experience stock out to fulfill the customer's demand. This analysis should be evaluated by the chief's store as the person responsible to maximize the inventory control process activities. It can be done in weekly, monthly, or yearly basis.

Also, Warteg ABC can use FIFO method to make sure the employee separate the old and new inventory and make sure that the first inventory sold is the first inventory that the MSME's buy, supplier relationship analysis to manage relationship with supplier and prepare alternative if the supplier cannot fulfill the order, and do regular audit such as stock opname to ensure the inventory record is reconciled with the physical. 
Below will be the offline improvement inventory control in the Microsoft excel form that the coach has made based from the discussion with the owner.

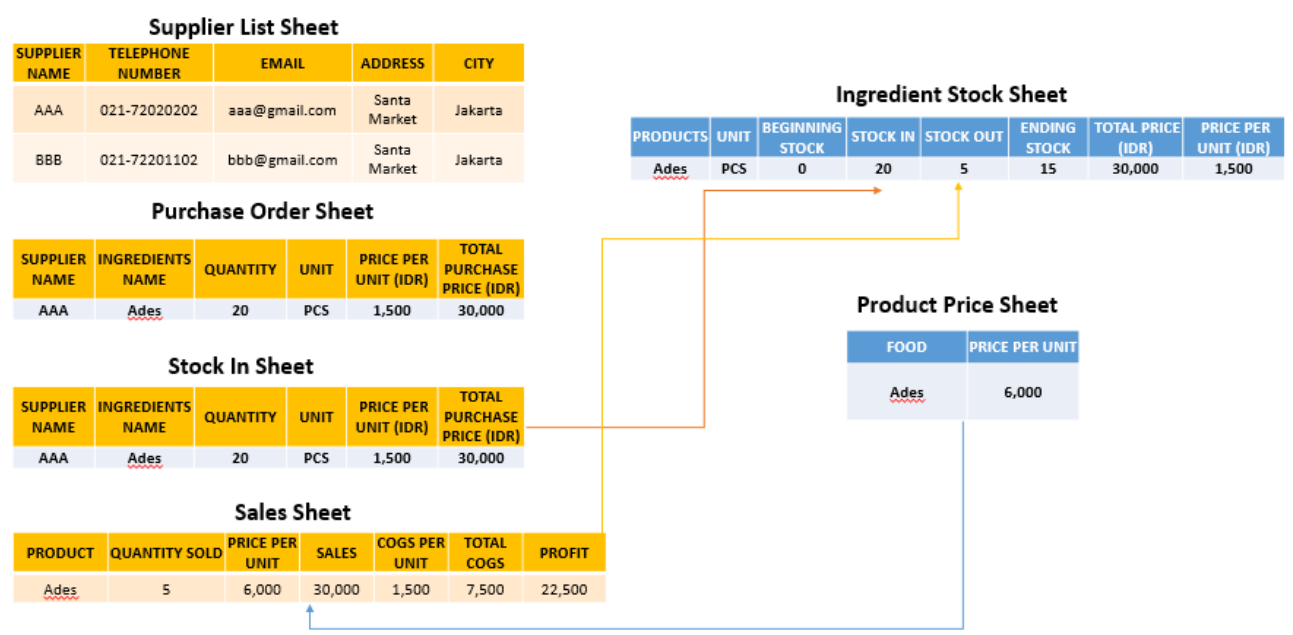

Fig. 1. Merchandising Product Inventory Control.

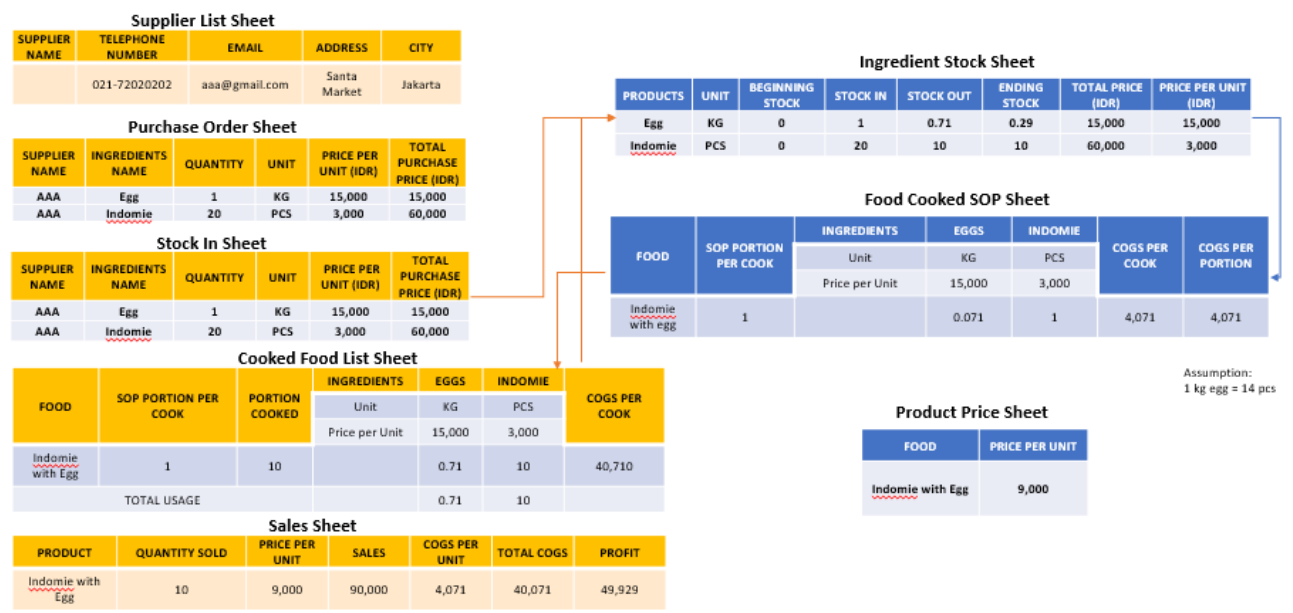

Fig. 2. Manufacturing Product Inventory Control.

Basically, merchandising and manufacturing product inventory control is more or less has the same process. The employee of Warteg ABC should update the supplier list sheet, purchase order sheet, stock in sheet, cooked food list sheet, and sales sheet on the daily basis. The ingredient stock sheet will be automatically updated based on the data that inputted in the stock in sheet, cooked food list sheet, and sales sheet. Stock in data in the ingredient stock sheet will be automatically updated when stock in sheet updated, that represented the ingredients received. The difference between merchandising product inventory control and manufacturing product inventory control will be in the stock out calculation in the ingredient stock sheet. In the merchandising product inventory control, stock out will be calculated based on the sales sheet that reflected the actual sales made. But in the manufacturing product inventory control, stock out will be calculated based on cooked food list sheet, which is reflected about how many food that cooked on a day that use defined Standard Operating Procedure that described about how many ingredients that needed to cook a food. 


\subsection{Implementation of Online Improvement}

The coach also provides suggestions for the owner of Warteg $\mathrm{ABC}$ to use online improvement solution by using POS Software provided by vendor in the market. Some reasons why POS software are important and will be useful for Warteg ABC:

a. POS software provide real time ending inventory balance

b. POS software have capability to maintain many stores

c. POS software provide segregation of duties between employee that have responsibility to purchase the inventory and the employee that sales the product

d. POS software will automatically record the sales from the sales made and deduct the inventory

e. POS software will also provide some analytic tools related to Warteg ABC sales and identify best and worst-selling products, and details the customer patterns.

f. POS software also can integrate sales with online application such as Go-Food and Grab-Food and also integrate with financial application such as Go-Pay, Ovo, etc.

g. POS software help the employee to easily order with the purchase order that sent to the supplier from the supplier list that already inputted in the software database.

With this many benefits that are provided from the POS Software, the coach also help the owner of Warteg ABC to compare three POS software that well-known as the best software that provided in the market, which are Pawoon, Moka, and Olsera.

Table 5. Vendor POS Software Comparation

\begin{tabular}{|c|c|c|c|c|}
\hline \multicolumn{2}{|c|}{ Comparation } & Pawoon & Moka & Olsera \\
\hline \multirow{4}{*}{ Implementation } & Set-up & $\mathrm{V}$ & V & V \\
\hline & Training & V & $\mathrm{V}$ & $\mathrm{V}$ \\
\hline & $\begin{array}{c}\text { Employee } \\
\text { Access }\end{array}$ & Unlimited & $\begin{array}{c}5 \text { slot front } \\
\text { office }\end{array}$ & Unlimited \\
\hline & $\begin{array}{l}\text { Operating } \\
\text { System }\end{array}$ & Android & Android & Android/Ios \\
\hline Input & Data & $\begin{array}{l}\text { Supplier and } \\
\text { Raw Material }\end{array}$ & $\begin{array}{l}\text { Supplier and } \\
\text { Raw Material }\end{array}$ & $\begin{array}{l}\text { Supplier and } \\
\text { Raw Material }\end{array}$ \\
\hline Process & Online/Offline & $\mathrm{V}$ & $\mathrm{V}$ & V \\
\hline \multirow{5}{*}{ Output } & Split Bill & $\mathrm{V}$ & $\mathrm{V}$ & $\mathrm{V}$ \\
\hline & E-payment & $\mathrm{V}$ & $\mathrm{V}$ & $\mathrm{V}$ \\
\hline & E-invoice & E-mail & E-mail & WA/E-mail \\
\hline & Sales Report & $\mathrm{V}$ & $\mathrm{V}$ & $\mathrm{V}$ \\
\hline & COGS Report & $\mathrm{V}$ & $\mathrm{V}$ & $\mathrm{V}$ \\
\hline \multicolumn{2}{|c|}{ Price Monthly } & IDR 299,000 & - & IDR 218,000 \\
\hline \multicolumn{2}{|c|}{ Price Yearly } & IDR $1,794,000$ & IDR $3,199,000$ & IDR $1,688,000$ \\
\hline
\end{tabular}

The significant different from the table, we can see that Moka Software only provide five employee access in the front office, but Pawoon and Olsera can provide unlimited access for both back office and front office. And last, the most significant different between those three POS Software are about the price. Only Pawoon and Olsera which can be subscribed by Warteg ABC on monthly basis. Moka POS Software did not provide subscription on monthly basis. But three of them can be subscribed on yearly basis but with slight difference in the purchase price. 
From the comparation between POS Software on the table, the owner of Warteg ABC tend to choose Pawoon POS Software. There are some reasons regarding this decision by the owner, first the Pawoon does not have limitation for the employee. The second one is that Pawoon offers low price, even not lower price than Olsera, but the owner of Warteg ABC feels that Pawoon is easier to use and user friendly than Olsera POS Software. And last, with this pandemic situation that uncertain, choose the vendor that can be subscribed on the monthly basis is deemed more appropriate for the owner to mitigate the hazard risk that can caused the business to temporarily close since the significant decrease of sales.

\section{Conclusion}

Based on the mapping analysis of Warteg $\mathrm{ABC}$ conditions and problem identification in its business process, as well as the application of solutions to fix the problems that are owned by MSMEs, then it can be concluded that MSMEs did not have clear control regarding the inventory. Because of that problem, then it is arranged for the MSMEs to use proper recorded information system. The information system is in the form of integrated Microsoft excel. Later, this information system can be automated by using POS software application, which will be integrated the inventory sold with the inventory balance.

In the inventory control and management, the coach also provide the owner of Warteg $\mathrm{ABC}$ some analysis tools regarding the purchase activities that management should do, such as demand forecasting which generated from the previous month sales and will be used as basis to calculate analysis such as, $\mathrm{ABC}$ analysis that is calculated by using the demand forecasting and unit price is expected to help the owner to have better attention to the most critical items and impact more to the Warteg ABC financial, safety stock that is calculated by using daily usage and lead time is expected to help the owner of Warteg ABC avoid the stock-out and affect the capability to fulfill the customer's demand, the usage of FIFO management inventory, manage relationship with the supplier, and do the physical inventory.

For the improvement solution whether it is offline or online solution, it is expected that the added benefits exceed the added costs, because Warteg $\mathrm{ABC}$ is expected to lower its inventory cost and operate more efficiently since Warteg $\mathrm{ABC}$ will become capable to mitigate the fraud risk from the employee, mitigate the spoilage inventory and dead stock inventory, and purchase the inventory from the supplier that provides lowest cost. The lower inventory and operation cost will lead to lower the price of food and beverages of Warteg $\mathrm{ABC}$, win the competition in the market and generate more sales to gain more profit and develop the branch stores in the various regions in Indonesia.

In the business coaching implementation timeline, the implementation of improvement solution for the problem in this research study should be scheduled in May 2020, but because of the Pandemic situation that makes the significant decreased for the sales and forced Warteg $\mathrm{ABC}$ to temporarily closed, the implementation of the solution along with the employee training will be delayed until Warteg $\mathrm{ABC}$ re-open the store if the situation in Jakarta already back into normal condition and people go to work as usual that hopefully the sales of Warteg $\mathrm{ABC}$ can also back to normal as before the Pandemic.

\section{References}

1. Dittmann, J. Paul. Supply Chain Transformation: Building and Executing an Integrated Supply Chain Strategy. New York: McGraw-Hill. (2012)

2. Schwarz, Lisa. Everything You Need to Get Started and Become More Efficient. (2020), from https://www.netsuite.com/portal/resource/articles/inventory-management/whatare-inventory-management-controls.shtml 
3. Campbell, Cassandra. You're Losing Money by Not Using These 8 Inventory Management Techniques. (2018) from https://www.shopify.com/blog/inventorymanagement

4. Biswas, Sarojit \& Karmaker, Chitra \& Islam, Ariful \& Hossain, Nazmul \& Ahmed, Shamim. Analysis of Different Inventory Control Techniques: A Case Study in a Retail Shop. Journal of Supply Chain Management System. 6. 35-45. (2017) 